\title{
Translation Strategies for Phonographic Deviations: A Psycholinguistic Approach
}

\section{Перекладацькі стратегії для фонографічних девіацій: психолінгвістичний підхід}

\section{Oleksandr Rebrii}

DSc. in Philology, Professor, Head of Mykola Lukash Translation

Studies Department

\author{
Олександр Ребрій \\ доктор філологічних наук, \\ професор, завідувач кафедри \\ перекладознавства \\ імені Миколи Лукаша
}

Ganna Tashchenko

Ph.D. in Philology,

Associate Professor

\section{Ганна Тащенко}

кандидат філологічних наук, доцент

E-mail: g.v.tashchenko@karazin.ua https://orcid.org/0000-0002-9008-4935

V.N. Karazin Kharkiv

National University

4, Svoboda Sq., Kharkiv,

Ukraine, 61022
Харківський національний університет імені В.Н. Каразіна

$\triangle$ майдан Свободи, 4, Харків, Україна, 61022

Original manuscript received November 18, 2019

Revised manuscript accepted September 25, 2020

\section{ABSTRACT}

The article proposes a psycholinguistic approach to investigating translation strategies on the basis of information obtained in the course of the retrospective experiment designed by the authors and defined as 'Partial Delayed Report of Problems and their 
Solution'. The aim of the research is to expose and describe translation strategies for resolving such a variety of translation difficulties as phonographic deviations. The object of the research is translation strategies as a mental by nature and complex by structure plan for the translator's actions. The subject of the research is specifics of the above strategies' formation and implementation in literary translation.

The main method of the research is retrospective experimental technique 'Partial Delayed Report of Problems and their Solution'; other methods employed include algorithmic modeling (for prospected translation strategies and substrategies) and comparative analysis (for control units in the source and target texts).

The material of the research was twofold: (1) the fragment of Charles Dickens's novel "The Posthumous Papers of the Pickwick Club» and its translations carried out by 21 semi-professional subjects of the experiment; (2) the subjects' reports in the form of the answers to the questionnaire completed and submitted after the translation. Since strategies in translation studies are mostly dealt with within cultural approach, the authors turned to the concept of communication strategies as a foundation of their own psycholinguistic model of translation strategies for phonographic deviations.

The analysis of the experimental data supports the conclusion that the translator initially forms a strategy (conscious mental plan) of overcoming a certain variety of translation difficulties (such as phonographic deviations) and then implements it as a sequence of moves (substrategies) aimed at providing for the most natural for the target reader translation variant.

Key words: equivalent, phonographic deviation, psycholinguistic model, retrospective experiment, translation difficulty, translation strategy.

\section{Introduction}

Translation process came into the focus of the researchers' attention in the 1980s when innovative experimental techniques were borrowed from psychology and adapted for translatological purposes. Since then, translation experiments - both introspective and retrospective, humanonly and machine-aided - have successfully contributed to better understanding of mental operations underlying the translator's decisionmaking as to the selection of target verbal means (García \& Giozza, 2019; Meister, 2017; Su, 2017), and thus can be viewed as a sui generis meeting point for translation studies and psycholinguistics. The topicality of the current research is determined by the fact that it allows to shed more light on translation strategies in their psycholinguistic dimension. The aim of the research is to expose and describe translation strategies for resolving such a variety of translation difficulties as phonographic deviations. Translation strategies as a mental by nature 
and complex by structure plan for the translator's actions serve as the object of research while specifics of their formation and implementation is its subject. The material is twofold: firstly, it is the fragment of Charles Dickens's novel «The Posthumous Papers of the Pickwick Club» and its translations carried out by 21 semi-professional subjects of the retrospective experiment; secondly, it is the subjects' reports in the form of the answers to the questionnaire completed and submitted after the translation.

Translation strategies have been a popular object of research for decades which accounts for a variety of their definitions. Yet, for most cases, the understanding of a strategy within translation studies falls under one of two major approaches. The first approach stems from Friedrich Schleiermacher's 'method' of translation which in the 20th century was transformed into such concepts as Juliane House's 'overt' and 'covert' translation, or Lawrence Venuti's 'foreignization' or 'domestication' strategies. This approach can be characterized as culturally-oriented, since «strategies of translation involve the basic tasks of choosing the foreign text to be translated and developing a method to translate it», and «both these tasks are determined by various factors: cultural, economic, political» (Venuti, 2005: 240). Venuti who is probably the most reputed propagator of strategy-related research in modern translation studies factually likens strategy to a method which not only completes the hermeneutic circle started by Schleiermacher but also gives green light to a legion of scholars aspiring to attribute the signs of either strategy to this or that translation.

The second approach is based on the concept of 'communication strategies' regarding that obvious fact that translation is a form of (interlinguistic and intercultural) communication. This approach has been fruitfully exploited in the field of second language acquisition (SLA), including future translators/interpreters training, but has sociolinguistic and psycholinguistic perspectives as well. Within this approach, the accent is made on three points that are of special importance for our research: communication strategy is seen as (1) a potentially conscious (2) mental plan for (3) problem-solving. Thus, psycholinguistic potential of communication strategies is determined by the attempts to embed them in a model of speech production.

Communication strategies are believed to be of universal character in the sense that they potentially cover any kind of speech 
behavior as well as all forms of linguistic material. Nevertheless, «in actual research practice researchers of different theoretical persuasions have focused on lexical difficulties» (Kasper \& Kellerman, 2014: 7). The fixation «on lexis is an immediate consequence of the definitional criterion of problematicity and the related issue of awareness» (ibid.). This observation is true for translation studies that has been elaborating on the concept of translation difficulties. Though translation difficulties are similarly understood as «lingual/speech formations of different levels that cause obstacles on the way of successful interlinguistic and intercultural communication due to objective differences in the structures and functioning of interacting languages as well as subjective perception of these differences by the translator» (Rebrii, 2012: 106), the researchers' attention is mostly and traditionally concentrated on their resolution at the lexical level.

\section{Methodology of the research}

From a psycholinguistic point of view, we follow the general model of communication strategy outlined by Nanda Poulisse: «The speaker who has planned his message needs to encode this at a certain stage. To do this he has to retrieve the appropriate words from his mental lexicon. If he is able to do this, language use is nonstrategic. If, however, his lexicon does not contain (one of) the required words, he needs to adopt a CS [communication strategy - O.R., H.T.]» (Poulisse, 1993: 160).

Indeed, the absence of (a) necessary equivalent(s) for (a) certain source unit(s) in the translator's mental lexicon drives him/her to accept one of the following possibilities: (1) (s)he can look it/them up in external sources (e.g., dictionaries); if this search yields no result (s)he can (2) coin the necessary equivalent(s) by himself/herself or (3) resort to any form of contextual compensation(s); finally, (s)he can (4) omit the unit(s) in question if its/their absence in the target text does not compromise its meaning and function. Within general typology of communication strategies, moves (1), (2) and (3) are characterized as 'compensatory' (or 'achievement') strategies, while move (4) belongs to 'reduction' (or 'avoidance') strategies (ibid.: 161).

At this point, another question arises: 'How can psycholinguistic translation strategies be detected?' Or, in other words, 'How can a 
researcher switch from hypothetical to empirical?' The answer, once again, can be found in the field of SLA where considerable effort has been made in this direction. In particular, Gabriele Kasper and Eric Kellerman claim the following: «Unless the task is such that it unambiguously elicits... problems and their solution, researchers thus have to rely on two sources of evidence to identify CS: markers in the discourse and retrospective protocols. The first comprise explicit strategy markers - metalinguistic comments of the 'I don't know how to say this' sort - and implicit indicators such as an increase in hesitation phenomena. The second method involves playback of the original discourse and self-identification of strategic activity by the informant» (Kasper \& Kellerman, 2014: 3-4). In order to verify this statement's validity in respect to translation strategies, we decided to devise and carry out our own retrospective experiment.

One of the vices most often ascribed to retrospective techniques is that they are «limited by the constraints of selective and working memory and, like all self-report methods, may result in recitations of ideal procedures rather than actual self-reflection» (Angelone, Ehrensberger-Dow \& Massey, 2016: 45). According to Karl Anders Ericsson and Herbert Alexander Simon, the type of retrospective report most closely related to introspective one [and thus, the most reliable O.R., H.T.] is based on asking the subjects to report (reproduce) their thoughts immediately after completing the task. Here, the scientists noticed the following pattern of the subjects' behavior: "When the time to generate the response is brief ( $1 \mathrm{~s}$ to $5 \mathrm{~s}$ ), it is likely that the participants can recall their sequence of thoughts reasonably accurately. Our review $<\ldots>$ showed that when participants are asked merely to recall their thoughts, the reported information is consistent with other observations of the same processes, such as latencies» (Ericsson, 2003: 13).

Proceeding from observations made during her own experiments, Ida Rambæk concludes that, on the one hand, retrospection «gives greater insight if one wishes to study the translator's global strategies or the cross-cultural aspects of translation» (Rambæk, 2004: 17), while, on the other hand, «the lack of verbalisation [in retrospective experiments - O.R., H.T.] may be taken as an indication that in some respects retrospective verbalisations are less complete than concurrent think-aloud» (ibid.: 8). Thus, the author believes that «in retrospective verbal reports the translators will express the awareness of the function 
of the translation, of the recipients and of own strategies, in a more global way than in concurrent thinking aloud» (ibid.: 7).

As one can see, most researchers agree on the fact that retrospective experiments are well suited for exposing communication strategies, including translation ones. Another obvious advantage of this method is that it allows to obtain the information that fits precisely the aim and tasks of the research by channeling the subjects' attention into the necessary direction through carefully formulated questions: «... translator interviews can provide better-quality data because they enable the researcher to put the same set of specially focused questions to a number of subjects, instead of allowing the translator to ramble at will» (Jones, 2007: 61).

Selecting specific issues to investigate is an important element of a successful retrospective experiment. A set of questions offered for the subjects' consideration must help them not just exteriorize past actions but do it to the researcher's benefit allowing him/her to elicit specific type of information. Developing this experiment, we followed Daniel Gile's methodology of Integrated Problem and Decision Reporting or IPDR. Initially elaborated as early as 1979 , it was employed as a didactic tool that provided the teacher with an opportunity to evaluate the students' progress and the students - to carry out translations in a more conscious way. Later on, the methodology was adapted for research needs:

"In its didactic version, IPDR proceeds in three phases, the reporting phase, the data analysis phase, and the instructor's response phase. In a research version, the third phase can be replaced or complemented with different or follow-up phases, for instance, with further questioning of students on specific problems, action, decisions or other phenomena» (Gile, 2004: 7).

Trying to adapt Gile's methodology for the purpose and conditions of our experiment, we made some corrections to it. Firstly, we tasked the subjects to report not all potential problems encountered in the course of translation, but to concentrate on the following questions: (1) What linguistic and/or stylistic phenomena in the source text can be referred to the category of translation difficulties and why? (2) Did you follow any particular strategies while resolving these difficulties, and if so, how can these strategies be described? (3) What linguistic 
and/or stylistic means were used as equivalents for exposed translation difficulties? Did you coin these means by yourself, and if so, how?

Our second correction concerned the time of submitting the subjects' reports. We intended to make it as close to the time of conducting translation as possible (as it was initially stipulated by Gile's methodology) but because the experiment was conducted at subjects' homes and their reports were sent by e-mail it was not always possible (we simply could not ensure the rigid control of the experiment's conditions and had to allow the subjects certain flexibility time-wise). Due to these corrections, we prefer to call our experiment Partial Delayed Report of Problems and their Solution or PDRPS.

The choice of the source text was substantiated by the fact that the selected short fragment includes 17 examples of phonographic deviations - changes in the word's spelling aimed at demonstrating the specifics of pronouncing this word due to some physiological conditions, health problems, accent, etc. In our case, the deviation was caused by the character's speech impediment known as 'rhotacism' - the inability to pronounce the sound $[\mathrm{r}]$. See example from the text:

"Gwacious heavens!» said his Lordship, "I thought evewebody had seen the new mail-cart; it's the neatest, pwettiest, gwacefullest thing that ever wan upon wheels. Painted wed, with a cweam piebald» (Dickens, n.d.).

As one can see, Dickens imitates Lord Mutanhead's burr by substituting letter ' $w$ ' for ' $r$ '. He diligently follows this technique throughout the fragment, and the deformed words obviously present the biggest translation difficulty which, nevertheless, can be coped with quite easily.

The experiment's subjects are 21 students of the Master's Degree program «The English Language, Literature and Translation» at the School of Foreign Languages of V.N. Karazin Kharkiv National University. As students, they have considerable theoretical background in the field of translation studies and good command of English, but obviously lack some practical translatorial experience. Taken together, these factors allow to qualify the experiment's subjects as semiprofessionals. Semi-professionals are believed to take their decisions in a more conscious fashion; at the same time, their professional competence is not fully formed yet and many processes are not automatized, they 
have no standard ways of overcoming different types of problems: "As far as attitudinal factors are concerned, the semi-professionals" ambivalent attitude toward paraphrasing and their fear of false friends can be interpreted as a lack of self-confidence» (Kussmaul \& TirkkonenCondit, 1995: 187). Though the original reports from the subjects were in Ukrainian, their fragments provided in the next section of the article were translated into English for the readers' convenience.

\section{Results of the experiment and discussion}

(1) The task of the first question was to identify phonographic deviations as a type of translation difficulties, i.e. as a problem whose resolution would require a special strategy. Quite predictably, most subjects fulfilled this task quite successfully, partially due to the recurrent character of the problem. Total of $16(76.0 \%)$ subjects explicitly identified this problem in their answers. It's interesting, that some of them pointed at the challenge in its physiological form (as the character's 'speech impediment', 'rhotacism', 'dyslalia' or, most often, 'burr'), while others gave preference to the difficulty's linguistic nomination. For this purpose they used the term 'phonographic stylization' or its domestic equivalent 'graphon'. Thus, they confirmed their theoretical awareness of this phenomenon. See, for instance, Report \#10: «... I came across phonographic stylizations which are also called 'graphons'. <..> During translation, phonographic stylizations may turn out quite a difficult phenomenon, because they belong to eternal problems of translation studies and automatically fall under the category of translation difficulties due to the absence of recurrent equivalents in the target language.»

As one can see from the above example, some subjects also added their explanations as to referring phonographic deviations to translation difficulties. In particular, such factors as the absence of regular equivalents and norm violation were mentioned. See, for instance, Report \#1: «They were difficult, because sometimes it was hard to find an equivalent which would sound in accordance with the author's style and would fit the period described.» Report \#7: «Another difficulty is connected with the personages' manner of speaking as the text is filled to the brim with violations of linguistic norms. And the 
difficulty here is not to notice them but to understand the reason of their introduction into the text and to reproduce them in a way that allows to convey the author's aim to the target audience.» Report \#19: «The hero in the text had a speech defect, namely burr. <..> That is why translation difficulties here include the reproduction of graphons, i.e. relevant violations of orthographic norms.»

Functional designation of phonographic deviations was sometimes indicated as an important factor complicating their translation. For instance, in Report \#13 it was expressed in rather abstract terms reminding more of the translator's general guidelines: «... the problem was in the main character's speech impediment, namely his burr. Since it was done by the author on purpose, it was simply impossible to miss this moment in the text.» Other subjects referred to the comic/humorous function of phonographic deviations that must be preserved in the target text. See, for instance, Report \#14: «It should also be mentioned that it was especially important to reproduce the comicality of the situation and respectful but somewhat ironic attitude of the other personages to the young lord.» Report \#17: «Obviously, the text contains comic elements that create a very lively and easy-going atmosphere while reading. English humor is indeed a very specific phenomenon that is why I believe that it also creates difficulties for the translator.»

(2) First of all, we should state that some subjects in their reports tied up answers to questions (2) and (3). Probably they did so because they could not separate strategies per se from the means of their implementation, but for the sake of further analysis, the information they submitted will be separated in accordance with the initial research plan. Also, 8 subjects (38.0\%) mentioned in their Reports Venuti's domestication or foreignization strategies, because, as we assume, those are the only possible translation strategies familiar to the students from their theoretical courses at the University. In fact, the subjects tried to adjust their understanding of these strategies to the current situation with phonographic deviations which led to somewhat paradoxical result: while in their translations analogical decisions were made, the subjects described them in conflicting terms. Take for instance, Report \#14 whose author reasoned her decisions by orientation towards the source text and its culture: «While translating this text I mainly followed foreignization strategy. $<\ldots>$ This strategy seemed appropriate to me, because the events described in the novel take 
place in England.» Compare to Report \#17 whose author claimed moving in the opposite direction: "While analyzing this fragment I gave preference to domestication strategy, that is to bringing the culture of the source text's author to the culture of the target language. Obviously, I tried to preserve certain culture-specific units in order not to lose the elements peculiar to that period.» Pondering on this interesting case, we came to the conclusion that extremely broad and vague interpretation of culturally-oriented translation strategies does not always allow researchers (especially beginner ones) to unequivocally ascribe one particular strategy to a particularly difficult or rare problem situation. Thus, some subjects' intention to unite both strategies in one seems like a suitable compromise. See, for instance, Report \#5: «During translation, I aspired to stick to the 'golden mean' strategy, to combine the elements of both domestication and foreignization, though I believe that for the translation of literary works it is better to be inclined to foreignization, because excessive ukrainization and bringing the text closer to cultural and linguistic peculiarities of a target country leads to the loss of the original's coloring.»

Returning to the object of our research - translation strategies in their psycholinguistic dimension - it should be stated that most subjects formulated them in accordance with our expectations. Though the wordings differed, the meaning was expressed quite clearly: the absence of ready-made equivalents for the author's phonographic deviations brought to the subjects' minds the idea of creating similar deviations in the target text on the basis of the target language words. According to the above model of translation strategy, 20 subjects $(95.0 \%)$ skipped move (1) as unnecessary (the absence of regular equivalents for contextual (de)formations was obvious) and opted for move (2) which falls under the category of 'compensatory' communication strategies, i.e. they created their own equivalents in the way that allowed to preserve the original function and stylistic coloring. See, for instance, Report \#10: "We see in the original text that in the words with ' $r$ ' it was substituted with ' $w$ ', which indicated the author's intention to let us know that the character has a speech impediment. It is here that I applied the strategy of parallel reproduction of the graphons by analogical means of the target language. $<\ldots>\ldots$ I deformed the words in such a way that would allow to guess with a high level of probability what exactly the author intended to say in the given context. 
Though in the original the spelling was violated the meaning remained quite understandable.» Report \#13: «The main strategy for translation was to select [the units] and compose the sentences in a way that would demonstrate the character's special feature - his burr. To this end, it was necessary to purposefully spell the words with mistakes in order to show the personage's speech impediment.»

(3) Trying to explain what «linguistic and/or stylistic means were used as equivalents for exposed translation difficulties» the subjects basically described their actions in the form of substrategies to a more general strategy formulated as the answer to question (2) of their task.

First of all, the subjects pointed out that the author substituted letter ' $w$ ' for letter ' $r$ ' in order to portray Lord Mutanhead's speech impediment, and thus, they figured out that the best possible way for the translator would be to imitate this method. See, for instance, Report \#7: "To demonstrate this [effect] letter ' $r$ ' in all the words that contained it was substituted with ' $w$ '. It was not hard to convey.» Report \#5: «In the source text the character pronounces [w] instead of $[\mathbf{r}]$ all the time. It was impossible to reproduce the burr in the direct equivalents of the deformed words, thus I decided to convey this defect in all the Ukrainian words with letter ' $p$ '.»"

The next important step was to decide what Ukrainian letters would be involved in the target substitution. Here, the subjects' opinions divided. The majority (15 or $71.0 \%$ ) opted for ' $p$ ' $\rightarrow$ ' $\Gamma$ ' transformation as the most natural for the Ukrainian 'ear' one. See, for instance, Report \#8: «In order to make the translated text look more natural, I used in my Ukrainian version letter ' $\boldsymbol{~}$ ' instead of letter ' $p$ '.» Report \#4: «... the main character has a burr which is portrayed in the original by substituting $[\mathrm{r}]$ with $[\mathrm{w}]$. In the Ukrainian language there are several variants for a similar substitution, namely: [p] with [в]; [p] with [г]; [р] with [д]; [р] with [й]; [р] with [л] or [л']. In my opinion, the most suitable variant is [p] with [г].» Others (5 or $23.0 \%$ ) gave preference to ' $p$ ' $\rightarrow$ 'B' transformation. See, for instance, Report \#1: «I intended to do everything in accordance with the author's conception; I mean I didn't hesitate as to the sound the character cannot pronounce. Since the author used letter ' $r$ ', it was logical for me to take [Ukrainian] letter ' $p$ '. I substituted ' $B$ ' for ' $p$ ' just like the author substituted ' $\mathbf{w}$ ' for ' $r$ '.,' 
For some subjects, the transformation was determined by the euphonic considerations. One such consideration in Report \#14 was stirred by the unwanted vocal resemblance between newly-coined equivalents and Ukrainian low register words: «At first, I tried to convey this type of dyslalia by substituting ' $\Gamma$ ' for ' $p$ ' which resulted in some funny variants that might puzzle a reader (чарівно - чагівно).» Another consideration was caused by the potential unpronounceability of new coinages. See, for instance, Report \#7: «Typically, we reproduce burr in Ukrainian texts just like this and I decided not to change the tradition. It was harder with the words where ' $p$ ' is followed by ' $\Gamma$ ' or the other way round like, for instance, іn 'найграціозніший'. In such cases the substitution of ' $\Gamma$ ' for ' $p$ ' creates a problem with pronouncing double ' $\Gamma$ '. As for me, it sets the teeth on edge <...>. I decided to use in such words an apostrophe sign instead of second ' $\Gamma$ '.

Finally, the selection of the letter for the transformation was determined by the character's age. See, for instance, Report \#11: "If we translate the speaking of a small child who hasn't learnt to pronounce [r] yet it should be reproduced by substituting ' $\pi$ ' for 'p'; but if we see this problem in the speech of an adult, it becomes obvious that we deal with the burr and adults with burr are inclined to pronounce $[p]$ like $[\Gamma]$; and that's exactly what should be done in translation.»

The next step of the strategic character was to find the equivalents that can be deformed in accordance with the subjects' previous decisions. Here again, one can observe several possible strategies. One of them was to favor those translation choices that contained letter ' $p$ ', and thus, could be deformed quite easily. See, for instance, Report \#20: «In the process of translation I found out that some equivalents of the deformed original lexemes didn't contain letter ' $p$ ' that could be changed; thus I had to infuse into my translation the words that would help compensate the burr.» As a result, the correlation between the number of phonographic deviations in the source and target texts was lost, though it did not seem like an important factor for the subjects. Only one of them verbalized his/her reflections on this matter. See Report \#11: "We see in the source text that the personage pronounces $[\mathrm{w}]$ instead of $[\mathrm{r}]$ which testifies to his burr. In a relatively short dialogue he deformed twenty words, thus I thought it desirable to reproduce approximately the same number of violations 
in my translation, though it was not necessary to reproduce this defect in direct equivalents. In practice, I even increased the number of such words - from twenty to twenty four - which, in my opinion, illustrated the author's idea even better.»

\section{Conclusions}

The analysis of the reports obtained from the participants of the retrospective PDRPS experiment together with translated texts themselves confirmed our hypothesis that translators follow particular strategies for resolving problem situations. Psycholinguistic interpretation of a translation strategy is opposed to the cultural one. It is based on the definition of a communicative strategy as a (potentially) conscious mental plan for decision-making in an ambiguous situation. According to the psycholinguistic model of translation strategy proposed in the current research, the translator first looks for a solution to a lexical translation difficulty in his/her mental lexicon and if this search fails then (s)he can check external sources (i.e. dictionaries), or coin an ad hoc equivalent by himself/herself, or turn to any type of a contextual (functional) compensation, or (as a very last resort) omit the difficulty in question in a target text. As the experiment proved, in case of (a relatively mild variety of) phonographic deviations caused by the character's physiological speech impediment, the majority of participants followed the same translation strategy of constructing their own equivalents of the deformed words which in fact mirrored the author's strategy in the source text. In the course of implementing this general strategy, the subjects followed a number of various substrategies aimed at providing for the naturalness of their translations for the potential Ukrainian reader.

\section{References}

Angelone, E., Ehrensberger-Dow, M., \& Massey, G. (2016). Cognitive Processes. In C. Angelelli \& B. Baer (Eds), Researching Translation and Interpreting (pp. 43-57). Abingdon: Taylor \& Francis Routledge.

Ericsson, K.A. (2003). Valid and Non-reactive Verbalization of Thoughts during Performance of Tasks: Toward a Solution to the Central Problems of Introspection as a Source of Scientific Data. Journal of Consciousness Studies, 10, 1-18. 
García, A.M., \& Giozza, M.C. (2019). Researching the invisible: multi-methodological developments in cognitive translatology. Perspectives, 27(4), 477-482. https://doi. org/10.1080/0907676X.2019.1595070

Gile, D. (2004). Integrated Problem and Decision Reporting as a Translator Training Tool. The Journal of Specialised Translation, 2, 2-20.

Jones, F.R. (2007). Unlocking the Black Box: Researching Poetry Translation Processes. In E. Loffredo \& M. Perteghella (Eds.), Translation and Creativity. Perspectives on Creative Writing and Translation Studies (pp. 59-74). London: Continuum.

Kasper, G., \& Kellerman, E. (2014). Introduction: approaches to communication strategies. In G. Kasper \& E. Kellerman (Eds.), Communication Strategies: Psycholinguistic and Sociolinguistic Perspectives (pp. 1-13). London, New York : Routledge, Taylor \& Francis Group.

Kussmaul, P., \& Tirkkonen-Condit, S. (1995). Think-Aloud Protocol Analysis in Translation Studies. TTR: traduction, terminologie, redaction, 8(1), 177-199. https://doi.org/10.7202/037201ar

Meister, L. (2017). On methodology: How mixed methods research can contribute to translation studies. Translation Studies, 11(1), 66-83. https://doi.org/10.1080/147 81700.2017.1374206

Poulisse, N. (1993). A Theoretical Account of Lexical Communication Strategies. In R. Schreuder \& B. Weltens (Eds.), The Bilingual Lexicon (pp. 157-189). Amsterdam/Philapelphia: John Benjamins Publishing Company. https://doi. org/10.1075/sibil.6.09pou

Rambæk, I. (2004). Translation strategies expressed in retrospective and concurrent verbal reports. Romansk Forum, 19, 7-19.

Rebrii, O.V. (2012). Suchasni kontseptsii tvorchosti u perekladi [Modern Concepts of Creativity in Translation]. Kharkiv: KhNU imeni V.N. Karazina [in Ukrainian].

$\mathrm{Su}, \mathrm{W}$. (2017). Psycholinguistic and cognitive inquiries into translation and interpreting. Perspectives, 25(2), 346-348. https://doi.org/10.1080/0907676X.2017.1284874

Venuti, L. (2005). Strategies of translation. In M. Baker (Ed.), Routledge Encyclopedia of Translation Studies (pp. 240-244). London, New York: Routledge, Taylor \& Francis Croup.

\section{Sources}

Dickens, Ch. (n.d.). The Pickwick Papers. Retrieved from https://www.gutenberg.org/ files/580/580-h/580-h.htm

\section{АНОТАЦІЯ}

у статті запропоновано психолінгвістичний підхід до вивчення проблеми перекладацьких стратегій на основі інформації, отриманої в перебігу розробленого авторами ретроспективного експерименту, що отримав назву "Частковий Відкладений звіт про Проблеми та їхнє Вирішення».

Мета дослідження полягає в тому, аби виявити та описати перекладацькі стратегії для розв'язання такого різновиду перекладацьких труднощів, як 
Перекладацькі стратегї̈ для фонографічних девіацій...

фонографічні девіації. Об’єктом дослідження $\epsilon$ перекладацькі стратегії як ментальний за природою та складний за структурою план дій перекладача. Предметом дослідження є особливості формування та втілення в художньому перекладі зазначених стратегій.

Провідним методом дослідження є ретроспективний експеримент; до інших задіяних методів належать алгоритмічне моделювання (для прогнозованих перекладацьких стратегій та субстратегій) та порівняльний аналіз (для зіставлення контрольних елементів у вихідному та цільовому текстах). Матеріал дослідження $\epsilon$ подвійним: (1) фрагмент з роману Чарльза Діккенса "The Posthumous Papers of the Pickwick Club» ma його переклади, здійснені 21 напівпрофесійним учасником ретроспективного експерименту; (2) звіти учасників експерименту у формі відповідей на питання, які інформанти надали по завершенню своїх перекладів. Оскільки стратегії вивчаються перекладознавцями переважно в межах культурного підходу, автори звернулися до поняття комунікативної стратегії як основи власної психолінгвістичної моделі перекладацьких стратегій для фонографічних девіацій.

Аналіз експериментальних даних дозволяє дійти висновку про те, що перекладач спочатку формує стратегію (свідомий ментальний план) подолання певної перекладацької труднощі (такої, як фонографрічні девіачії), а потім імплементує їі як послідовність кроків (субстратегій), скерованих на забезпечення найбільш природного варіанту перекладу.

Ключові слова: відповідник, перекладацька стратегія, перекладацька трудність, психолінгвістична модель, ретроспективний експеримент, фонографічна девіація.

\section{Ребрий Александр \& Тащенко Анна. Переводческие стратегии для фонографических девиаций: психолингвистический подход}

\section{АННОТАЦИЯ}

Статья предлагает психолингвистический подход к изучению переводческих стратегий на основе информации, полученной в ходе разработанного авторами ретроспективного эксперимента, который получил название «Частичный Отложенный Отчет о Проблемах и их Решении».

Цель исследования заключается в том, чтобы выявить и описать переводческие стратегии для преодоления такой разновидности переводческих трудностей, как фонографические девиации. Объектом исследования являются переводческие стратегии как ментальный по своей природе и сложный по своей структуре план действий переводчика. Предметом исследования являются особенности формирования и реализации упомянутых стратегий.

Ведущим методом исследования является ретроспективный эксперимент; среди других методов - алгоритмическое моделирование (для прогнозируемых переводческих стратегий и субстратегий) и сравнительный анализ (для сопоставления контрольных элементов в исходном и целевом текстах). 
Материал исследования двойственный: (1) фрагмент из романа Чарльза Диккенса "The Posthumous Papers of the Pickwick Club» и его переводы, выполненные 21 полупрофессиональным участником ретроспективного эксперимента; (2) отчеты участников эксперимента в форме ответов на вопросы, полученные от информантов по завершению переводов. Поскольку стратегии изучаются переводоведами преимущественно в пределах культурологического подхода, авторы обратились к концепции коммуникативных стратегий как основы собственной психолингвистической модели переводческих стратегий для фонографических девиаций.

Анализ экспериментальных данных позволяет сделать вывод о том, что, переводчик сначала формирует стратегию (осознанный ментальный план) преодоления определенной переводческой трудности (такой, как фонографические девиации), а потом имплементирует ее как последовательность шагов (субстратегий), направленных на обеспечение наиболее естественного варианта перевода.

Ключевые слова: переводческая стратегия, переводческая трудность, психолингвистическая модель, ретроспективный эксперимент, соответствие, фонографическая девиачия. 